\title{
Prevalence of 185delAG and 5382insC mutations in BRCA1, and 6174delT in BRCA2 in women of Ashkenazi Jewish origin in southern Brazil
}

\author{
Crisle Vignol Dillenburg ${ }^{1 *}$, Isabel Cristina Bandeira ${ }^{1 *}$, Taiana Valente Tubino ${ }^{1}$, Luciana Grazziotin Rossato ${ }^{1}$, \\ Eleonora Souza Dias ${ }^{2}$, Ana Cristina Bittelbrunn ${ }^{3}$, Sandra Leistner-Segal ${ }^{1,4}$ \\ ${ }^{1}$ Banco de DNA/Tecido de Mama e Ovário, Centro de Pesquisas Experimentais, \\ Hospital de Clínicas de Porto Alegre, RS, Brazil. \\ ${ }^{2}$ Hospital Materno Infantil Presidente Vargas, Porto Alegre, RS, Brazil. \\ ${ }^{3}$ Serviço de Mastologia,Hospital de Clínicas de Porto Alegre, RS, Brazil. \\ ${ }^{4}$ Laboratório de Genética Molecular, Serviço de Genética Médica, Hospital de Clínicas de Porto Alegre, \\ RS, Brazil.
}

\begin{abstract}
Certain mutations in BRCA1 and BRCA2 genes are frequent in the Ashkenazi Jewish population. Several factors contribute to this increased frequency, including consanguineous marriages and an event known as a "bottleneck", which occurred in the past and caused a drastic reduction in the genetic variability of this population. Several studies were performed over the years in an attempt to elucidate the role of $B R C A 1$ and $B R C A 2$ genes in susceptibility to breast cancer. The aim of this study was to estimate the carrier frequency of certain common mutations in the BRCA1 (185delAG and 5382insC) and BRCA2 (6174delT) genes in an Ashkenazi Jewish population from Porto Alegre, Brazil. Molecular analyses were done by PCR followed by RFLP (ACRS). The carrier frequencies for BRCA1 185delAG and 5382ins $C$ were 0.78 and 0 respectively, and 0.4 for the BRCA26174deT mutation. These findings are similar to those of some prior studies but differ from others, possibly due to excluding individuals with a personal or family history of cancer. Our sample was drawn from the community group and included individuals with or without a family or personal history of cancer. Furthermore, increased dispersion among Ashkenazi subpopulations may be the result of strong genetic drift and/or admixture. It is therefore necessary to consider the effects of local admixture on the mismatch distributions of various Jewish populations.
\end{abstract}

Key words: Ashkenazi Jews, breast cancer, BRCA1, BRCA2, mutation.

Received: January 19, 2012; Accepted: June 1, 2012.

Several factors may be responsible for the development of breast and ovarian cancers, but one of the most important described so far is the presence of $B R C A 1$ and $B R C A 2$ (BReast CAncer predisposition gene $1 / 2$ ) gene mutations. Although hereditary breast cancer accounts for only $5 \%-10 \%$ of recorded cases, individuals with mutations in these genes usually have $40 \%-80 \%$ higher odds of developing breast cancer (Claus et al., 1991; Easton et al., 1995; Schubert et al., 1997). Even though several studies attempted to understand how BRCA1 and BRCA2 mutations could influence cancer susceptibility, the variation in risk among carriers of these mutations is not yet clear. In certain groups, the frequency of mutations in these genes is higher, as observed in Ashkenazi Jews, where BRCA1/2 mutations

Send correspondence to Sandra Leistner-Segal. Laboratório de Genética Molecular, Serviço de Genética Médica, Hospital de Clínicas de Porto Alegre, Rua Ramiro Barcelos 2350, 90035-903 Porto Alegre, RS, Brazil. E-mail: ssegal @ hcpa.ufrgs.br. *The two first authors contributed equally to this work. are present at a rate of 2\%-3\% (Neuhausen et al., 1996; Roa et al., 1996; Levy-Lahad et al., 1997). In this group, the three most frequently found mutations are: $185 \mathrm{delAG}$ and 5382insC in BRCA1 and 6174delT in BRCA2, and more than $12 \%$ of the women who develop breast cancer bear one of these mutations (King et al., 2003). Population studies corroborate the hypothesis that these common mutations in $B R C A 1$ and $B R C A 2$, which are frequent in Ashkenazi Jews, are involved in predisposition to hereditary breast cancer (Neuhausen et al., 1996; Offit et al., 1996). The Ashkenazi Jewish population is prone to a series of genetic diseases, including cancers, blood disorders, and biochemical disorders, possibly due to a genetic bottleneck phenomenon followed by a period of rapid population growth, which are likely to have produced the conditions that led to a high frequency of many alleles associated with such genetic diseases (Goodman, 1979; Risch et al., 2003).

This study was approved by the Hospital de Clinicas de Porto Alegre Research Ethics Committee (\#04-208), 
which is recognized by the Office for Human Research Protections as an Institutional Review Board (IRB0000921). After obtaining informed consent, blood samples were collected from 330 female subjects during a Jewish community festivity in the city of Porto Alegre, southern Brazil.

Each of the volunteers reported the birthplace of her mother, grandmother, and in a few cases, greatgrandmother, and also completed an epidemiological questionnaire. Ashkenazi Jewish origin was confirmed in 255 women, thus excluding from the total sample 75 individuals who are only part Jewish.

DNA was extracted from peripheral blood using a standard salt precipitation technique described by Miller et al. (1988). Samples were stored in a DNA biobank at $-20^{\circ} \mathrm{C}$ until analysis. Molecular analysis was initially performed by PCR of exons 2 and 20 for $B R C A 1$ gene mutations and exon 11 for the $B R C A 2$ mutation, followed by $1 \%$ agarose gel electrophoresis and staining with ethidium bromide. Mutations were identified using the ACRS (Amplification Created Restriction Site) technique as described by Rohlfs et al. (1997). The restriction enzymes used were DdeI (185delAG), BstNI (5382insC) and EcoRI (6174delT) (all from New England Biolabs). The digested fragments were visualized on $3 \%$ agarose gel electrophoresis stained with ethidium bromide. Statistical analysis of mutation frequencies was performed using the Stata 7.0 program (StataCorp, College Station, TX, USA).

Regarding BRCA1 results, we found a carrier frequency of $0.78(2 / 255 ; 95 \% \mathrm{CI} 0.10-2.8)$ for $185 \mathrm{delAG}$ and no mutated alleles for 5382insC. For the 6174delT BRCA2 mutation, we found a carrier frequency of 0.4 (1/255; 95\% CI 2.45-8.08). Comparative data regarding similar studies conducted with Ashkenazi Jews worldwide are shown in Table 1.
Epidemiological data from the participants of the present study showed that, of the three positive results for the tested mutations, all subjects had a family history of cancer and two had a personal one. One of the women who were positive for the $185 \mathrm{delAG}$ mutation died of breast cancer, and several cases of various types of cancer were reported in her family (twin sister, two brothers, aunt and maternal cousin). The subject who was positive for a $6174 \mathrm{del} T$ mutation had a personal history of ovarian cancer and a family history of breast cancer (paternal grandmother).

Struewing et al. (1997) found 120 positive results for the common mutations described here. Of the 5,318 participants tested for BRCA1, 41 exhibited the 185 delAG mutation and 20 were positive for 5382 insC. Tests for the BRCA2 mutation involved 5,087 participants, 59 of whom exhibited the $6174 \mathrm{delT}$ mutation. Among the 120 mutation-positive subjects, $8.9 \%$ had a personal history of breast or ovarian cancer and $3.8 \%$ had first-degree relatives with such cancers. Nevertheless, the study shows that there could be unequal penetrance depending on the mutation found, supporting the hypothesis of heterogeneity of the allelic risk conferred by the different mutations (Antoniou et al., 2003).

Claus et al. (1998) studied the correlation between cancer and multiple factors which could be involved in its development. These factors included ethnic group, age at menarche and first pregnancy, familial inheritance, and others. Correlations corroborated through statistical tests showed a close relationship between epidemiological data and cases of breast cancer.

The etiology of familial breast cancer is complex and involves genetic and environmental factors, such as hormonal and lifestyle factors. Understanding familial aggregation is the key to understanding the causes of breast

Table 1 - Carrier frequency of common mutations in BRCA1/2 in Ashkenazi Jews described in several populations worldwide.

\begin{tabular}{lcccl}
\hline 185delAG & 5382insC & 6174delT & $N$ & Reference \\
\hline 0.78 & 0 & 0.4 & 255 & Present study \\
6.7 & 2.2 & 4.5 & 199 & Abeliovich et al., 1997 \\
23.3 & 3.0 & 8.9 & 605 & Chetrit et al., 2008 \\
1.05 & 0.12 & 1.05 & 1.715 & Fodor et al., 1998 \\
18.5 & 3.7 & 7.4 & 55 & Gershoni-Baruch et al., 1999 \\
7.0 & 1.6 & 5.9 & 184 & Hodgson et al., 1999 \\
0 & 0 & 0 & 92 & Kadouri et al., 2009 \\
4.2 & 2.5 & 3.7 & 1008 & King et al., 2003 \\
0.34 & 0.17 & 0.51 & 586 & Kirchhoff et al., 2004 \\
20.7 & 6.7 & 13.9 & 208 & Moslehi et al., 2000 \\
0.77 & 0.37 & - & $5318^{\mathrm{a}}$ & Struewing et al., 1997 \\
- & - & 1.16 & $5087^{\mathrm{b}}$ & Struewing et al., 1997 \\
6.3 & 1.9 & 3.6 & 412 & Warner et al., 1999 \\
\hline
\end{tabular}

${ }^{\mathrm{a}}$ : Number of patients tested for BRCA1 (185delAG and 5382insC)

${ }^{b}$ : Number of patients tested for BRCA2 (6174delT). 
cancer and facilitating development of effective prevention and treatment strategies (John et al., 2004).

Several studies based on frequency estimates of common BRCA1/2 mutations found a correlation between susceptibility to or development of cancer and presence of these mutations. Analysis of the genetic identity of populations prone to developing a series of diseases, such as Ashkenazi Jews, and identification of the epidemiologic factors involved in the personal and familial history of these individuals is, thus, of great value for genetic counseling and for developing new therapies seeking to provide more individualized treatment for better clinical response.

\section{Acknowledgments}

We would like to thank all women who took part in this study. This research was supported by the HCPA Institutional Research Fund (FIPE-HCPA). ICB received a CAPES grant. SLS is a CNPq research fellow.

\section{References}

Abeliovich D, Kaduri L, Lerer I, Weinberg N, Gail A, Sagi M, Zlotogora J, Heching N and Peretz T (1997) The founder mutations 185delAG and 5382insC in BRCA1 and 6174 delT in BRCA2 appear in $60 \%$ of ovarian cancer and $30 \%$ of early-onset breast cancer patients among Ashkenazi women. Am J Hum Genet 60:505-514.

Antoniou A, Pharoah PDP, Narod S, Risch HA, Eyfjord JE, Hopper JL, Loman N, Olsson H, Johannsson O, Borg A et al. (2003) Average risks of breast and ovarian cancer associated with $B R C A 1$ or $B R C A 2$ mutations detected in case series unselected for family history: A combined analysis of 22 studies. Am J Hum Genet 72:1117-1130.

Chetrit A, Hirsh-Yechezkel G, Ben-David Y, Lubin F, Friedman E and Sadetzki S (2008) Effect of BRCA1/2 mutations on long-term survival of patients with invasive ovarian cancer: The national Israeli study of ovarian cancer. J Clin Oncol 26:20-25.

Claus EB, Risch N and Thompson WD (1991) Genetic analysis of breast cancer in the cancer and steroid hormone study. Am J Hum Genet 48:232-242.

Claus EB, Schildkraut J, Iversen ES, Berry D and Parmigiani G (1998) Effect of BRCA1 and BRCA2 on the association between breast cancer risk and family history. J Natl Cancer Inst 90:1824-1829.

Easton DF, Ford D and Bishop DT (1995) Breast and ovarian cancer incidence in BRCA1-mutation carriers. Breast Cancer Linkage Consortium. Am J Hum Genet 56:265-271.

Fodor FH, Weston A, Bleiweiss IJ, McCurdy LD, Walsh MM, Tartter PI, Brower ST and Eng CM (1998) Frequency and carrier risk associated with common BRCA1 and BRCA2 mutations in Ashkenazi Jewish breast cancer patients. Am J Hum Genet 63:45-51.

Gershoni-Baruch R, Dagan E, Fried G, Kepten I and Robinson E (1999) BRCA1 and BRCA2 founder mutations in patients with bilateral breast cancer. Eur J Hum Genet 7:833-836.

Goodman RM (1979) Genetic Disorders Among the Jewish People. 1st edition. Johns Hopkins University Press, Baltimore, $512 \mathrm{pp}$.
Hodgson SV, Heap E, Cameron J, Ellis D, Mathew CG, Eeles RA, Solomon E and Lewis CM (1999) Risk factors for detecting germline BRCA1 and BRCA2 founder mutations in Ashkenazi Jewish women with breast or ovarian cancer. J Med Genet 36:369-373.

John EM, Hopper JL, Beck JC, Knight JA, Neuhausen SL, Senie RT, Ziogas A, Andrulis IL, Anton-Culver H, Boyd N et al. (2004) The breast cancer family registry: An infrastructure for cooperative multinational, interdisciplinary and translational studies of the genetic epidemiology of breast cancer. Breast Cancer Res 6:375-389.

Kadouri L, Temper M, Grenader T, Abeliovich D, Hamburger T, Peretz T and Lotem M (2009) Absence of founder BRCA1 and BRCA2 mutations in cutaneous malignant melanoma patients of Ashkenazi origin. Fam Cancer 8:29-32.

King MC, Marks JH and Mandell JB (2003) Breast and ovarian cancer risks due to inherited mutations in BRCA1 and BRCA2. Science 302:643-646.

Kirchhoff T, Satagopan JM, Kauff ND, Huang H, Kolachana P, Palmer C, Rapaport H, Nafa K, Ellis NA and Offit K (2004) Frequency of BRCA1 and BRCA2 mutations in unselected Ashkenazi Jewish patients with colorectal cancer. J Natl Cancer Inst 96:68-70.

Levy-Lahad E, Catane R, Eisenberg S, Kaufman B, Hornreich G, Lishinsky E, Shohat M, Weber BL, Beller U, Lahad A et al. (1997) Founder BRCA1 and BRCA2 mutations in Ashkenazi Jews in Israel: Frequency and differential penetrance in ovarian cancer and in breast-ovarian cancer families. Am J Hum Genet 60:1059-1067.

Miller SA, Dykes DD and Polesky HF (1988) A simple salting out procedure for extracting DNA from nucleated cell. Nucleic Acids Res 16:1215.

Moslehi R, Chu W, Karlan B, Fishman D, Risch H, Fields A, Smotkin D, Ben-David Y, Rosenblatt J and Russo D et al. (2000) BRCA1 and BRCA2 mutation analysis of 208 Ashkenazi Jewish women with ovarian cancer. Am J Hum Genet 66:1259-1272.

Neuhausen SL, Mazoyer S, Friedman L, Stratton M, Offit K, Caligo A, Tomlinson G, Cannon-Albright L, Bishop T, Kelsell D et al. (1996) Haplotype and phenotype analysis of six recurrent BRCA1 mutations in 61 families: Results of an international study. Am J Hum Genet 58:271-280.

Offit K, Gilweski T, McGuire P, Schluger A, Hampel H, Brown $\mathrm{K}$, Swensen J, Neuhausen S, Skolnick M, Norton L et al. (1996) Germline BRCA1 185delAG mutation in Jewish women with breast cancer. Lancet 347:1639-1943.

Risch N, Tang H, Katzenstein H and Ekstein J (2003) Geographic distribution of disease mutations in the Ashkenazi Jewish population supports genetic drift over selection. Am J Hum Genet 72:812-822.

Roa BB, Boyd AA and Richards CS (1996) Ashkenazi jewish population frequencies for common mutations in BRCA1 and BRCA2. Nat Genet 14:185-187.

Rohlfs EM, Learning WG, Friedman KJ, Couch FJ, Weber BL and Silverman LM (1997) Direct detection of mutations in the breast and ovarian cancer susceptibility gene BRCA1 by PCR-mediated site-directed mutagenesis. Clin Chemistry 43:24-29.

Schubert EL, Lee MK, Mefford HC, Argonza RH, Morrow JE, Hull J, Dann JL and King MC (1997) BRCA2 in American families with four or more cases of breast or ovarian cancer: 
Recurrent and novel mutations, variable expression, penetrance, and the possibility of families whose cancer is not attributable to BRCA1 or BRCA2. Am J Hum Genet 60:1031-1040.

Struewing JP, Hartge P, Wacholder S, Baker SM, Berlin M, McAdams M, Timmerman MM, Brody LC and Tucker MA (1997) The risk of cancer associated with specific mutations of BRCA1 and BRCA2 among Ashkenazi Jews. N Engl J Med 336:1401-1408.
Warner E, Goodwin P, Foulkes W, Meschino W, Goss P, Ozcelik H, Allingham-Hawkins D, Hamel N, Di Prospero L, Contiga $\mathrm{V}$ et al. (1999) Prevalence and penetrance of BRCA1 and BRCA2 mutations in unselected Ashkenazi Jewish women with breast cancer. J Natl Cancer Inst 91:1241-1247.

Associate Editor: Jeremy A. Squire

License information: This is an open-access article distributed under the terms of the Creative Commons Attribution License, which permits unrestricted use, distribution, and reproduction in any medium, provided the original work is properly cited. 